\title{
制振制御を加味した負荷無反応形サーボ系
}

\author{
岡 本 清 和*・水 谷 隆**.張 玉 武**.山極 高**
}

\section{Load Insensitive Servomechanism with Damping Compensator}

\author{
Kiyokazu Oкамото*, Takashi Mizutani**, Yu-Wu Zhang** and Takashi Yamagiwa**
}

To meet the increasing demands for the more refined semiconductor design rules and the more enhanced optical disk memory density, a very fine motion control based upon numerical control technology such as under submicron meter encoder feedback is required. The first major subject is how to keep a desired motion clear of elasticity of feeding mechanism. The second one is how to keep a load insensitive motion free from change of load and influence of disturbance. In this paper, a new damping compensator is derived from adopting both input side and output side detecting signals of the elastic feeding mechanism, which are processed through an each element being its relative degree equal to zero and are combined to generate a feedback information. Then, by using the compensator dominating the motion characteristics of the elastic member, a servomechansim with a position, a velocity and a acceleration control loop is organized and comes to show load insensitivity. The paper describes design methods of the proposed compensator and the servomechanism, and also shows the effectiveness by computer simulations.

Key Words: servomechanism, load insensitivity, elastic feeding mechanism, damping compensator, relative degree

\section{1.はじめに}

数值制御による運動制御において，位置検出エンコ ーダの分解能を向上させて高精度制御を実現しようと すると, 第一に直面する技術課題は送り機構の低剛性

†ロボティクス・メカトロニクス講演会 '90 で発表 $(1990 \cdot 6)$

* 日本電気 (株) 東京都港区芝 5-7-1

** (株) ミツトヨ 川崎市高津区坂戸 165

* NEC Corporation, Minato-ku, Tokyo

** Mitutoyo Corporation, Kawasaki

(Received August 8, 1990)

(Revised January 22, 1991)
亿対する制振制御である，さらに，生産性を高めるた めに高加減速の制御を行うと，その制振制御は一層重 要になる。 また，高精度制御においては被制御体の特 性変動や負荷変動あるいは印加される外乱に対しても 被制御体の挙動がその影響を受けない，すなわち負荷 無反応であるととが大切である.

負荷無反応化のための基本的な方策は制御ループの ハイゲイン化であり，負荷無反応形サーボ機構 ${ }^{1)-3) や ~}$ 外乱トルクオブザーバによる前向き補償 ${ }^{4), 5)}$, 加速度 制御形サーボ系 ${ }^{61,7)}$ などが提案されている。一方，制 振制御のための方策としてノッチフィルタの利用 ${ }^{8)}$, 2 次遅れ要素による補償9), 加速度のポジティブフィ ードバック制御 ${ }^{10)}, \mathrm{IP}$ 制御 $^{111,12)}$ ，オブザーバの応用 ${ }^{13)}$ などが報告されている。

本論文では, サーボモータ, パワー増幅器, 直動送 り機構に結合されたテーブル機構ならびにモータおよ びテーブルに取り付けられたセンサからなる実系を被 制御体として，新しい制振制御方式を提案し，負荷無 反応形サーボ系として制御システムを構成する方法に ついて述べる。

ここで提案する制振制御方式では，実系を非振動的 要素でその伝達関数の分子分母の次数差（相対次数） が $0 \sim-2$ の部分と振動的要素を含む部分とに分け, その振動的要素の遅れを補償するととで八イゲイン化 を図るとともに補償器に所望の応答特性を含ませるも のとなっている。また，ての補償器では振動的要素の 入力側と出力側との検出可能な運動情報を用い，それ らはともに相対次数が零の伝達要素を介して合成され フィードバック情報を生成している，それによって位 置, 速度, 加速度のループをむつ制御系が構成され負 荷無反応性を有するようになっている。

な抢，本論文に扔いては提案する補償器の構成之そ れが有効である条件を示し，位置制御ループまでの設 計方釗について述べる.さらに本方式の有効性を確認 するためのシミュレーション結果を示す. 


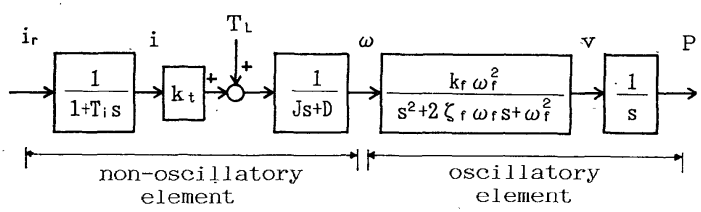

Fig. 1 Model of controlled object

\section{2. 実系の特性}

実系は, 電流制御ループをむつパワー増幅器とモー 夕からなる非振動的要素と, カップリング, 送り ネジ，テーブルからなる振動的要素からなり，Fig. 1 のようにモデリングできる15). ことで， $T_{i}$ はモータ の電流制御ループの時定数であり， $k_{t}$ はモータのト ルク定数である. $J$ とはモータのロータおよび負荷 のモータ軸換算の慣性モーメントと粘性摩擦係数であ り, $\omega_{f}$ 之 $\zeta_{f}$ は負荷の固有角周波数之減衰係数であ

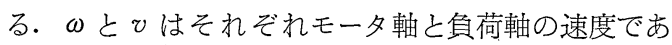
り， $k_{f}$ は送り係数である. $T_{L}$ はモー夕軸が送り機 構から受けた反作用トルクや外乱トルクなどを表わし ている。

一般に, 低剛性の送り機構をもつ負荷においては, その固有角周波数 $\omega_{f}$ は数 $\mathrm{Hz}$ 数十 $\mathrm{Hz}$ 程度であり, かつその減衰係数 $\zeta_{f}$ は 1 よかなり小さいことが多 w.

\section{3. 制振補償器の導出と負荷無反応形 サーボ系の構成}

まず，ここで提案する制振補償器に関する一般的な 考え方を示す．いま，Fig. 1 のモデルのように被制 御体は非振動的要素と振動的要素とからなるすのとす ると, 一般的に前者の相対次数（分子の次数一分母の 次数) は $0 \sim-2$ の值をもち, 後者の相対次数は低剛 性送り機構の特性を考慮すると少なくともー2を含む ことになる．乙こで非振動的要素と振動的要素の伝達 関数をそれぞれ $1 / G_{r} ; 1 / G_{f}$ とすると Fig. 2 のよう になる. むし， $v_{0} を v_{c}$ へ単純にフィードバックした 場合にはループ内の遅れの影響によってハイゲイン化 が妨げられることは明らかである。そこで，てのルー

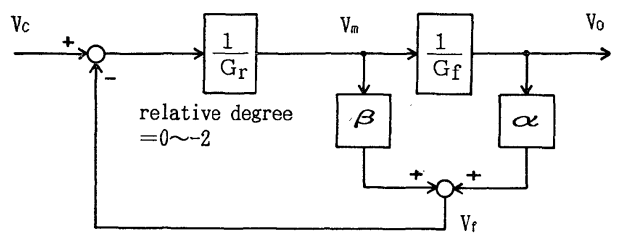

Fig. 2 Basic scheme of proposed compensator
プの一巡伝達関数の相対次数を，0〜ー2 亿収めるよう な補償器を構成し，ハイゲインによる安定化の実現を 考える.

このため, Fig. 2 のように振動的要素の入力側と 出力側の運動情報をそれぞれ相対次数零の伝達要素 $\alpha$ と $\beta$ を介して結合しフィードバック量を作る。すなわ ち,

$$
v_{f}=\alpha v_{0}+\beta v_{m}=\left(\alpha+\beta G_{f}\right) v_{0}=G_{n} v_{0}
$$

とおけば， $G_{f}$ と $G_{n}$ の次数は等しく， $v_{f}$ をフィード バックするととによっててのループの相詨次数は低減 し，振動的要素の相対次数の影響を回避することがで きる。 また，(1)式の関係から

$$
\beta=\left(G_{n}-\alpha\right) / G_{f}
$$

となるが，分母となる $G_{f}$. は正確に知るととあるいは 設定することが困難である，そこで，乙こではモデル の関数として $G_{m}$ を導入し，（3)式のように $\beta$ を定 め.

$$
\beta=\left(G_{n}-\alpha\right) / G_{m}
$$

$\beta$ の相対次数は零であり, このことは積分要素のみに よって実現できることを意味し工学的に重要である.

Fig. 1 の反作用トルクの影響は，等価的にモータ 之負荷の伝達特性の極の移動をもたらすが非振動，振 動的特性は保たれ，相対次数は変わらず(1)式も成立 する。

以上の構成によって, 一巡ループの相対次数は 0 〜 -2 に収められ，ハイゲイン化が実現できる.このと とは負荷無反応化にとって重要である. また, 結果と してフィードバック要素に含まれる $G_{n}$ が制御系の特 性を支配することになる。本論文では，制振の目的を 達成するために $G_{n}$ 亿非振動的な特性（減衰係数 $\geqq 1$ ) を与えることになる。また，速応性については $G_{n}$ の 主要固有角周波数によって指定する.

以上の考え方に従って，Fig. 1 の被制御体に対し て制振補償器を構成し, また非振動的要素部分に対す 万負荷無反応性も考慮して, 位置, 速度ならびに加速 度の制御ループからなる負荷無反応形サーボ系を構成 すると Fig. 3 のようになる. 以下外乱 $T_{L}$ は独立と して扱う.

ここで, 実系の振動的特性 $G_{f}$, 制振補償器におけ る指定特性 $G_{n}$, 同じくモデル特性 $G_{m}$ ならびに各制 御ループの補償器 $G_{a_{c}}, G_{v c}, G_{p_{c}}$ はつぎのようにす $ろ^{7)}$.

$$
\begin{aligned}
& G_{f}(s)=\left(s^{2}+2 \zeta_{f} \omega_{f} s+\omega_{f}^{2}\right) / \omega_{f}^{2} \\
& G_{m}(s)=\left(s^{2}+2 \zeta_{m} \omega_{m} s+\omega_{m}^{2}\right) / \omega_{m}^{2} \\
& G_{n}(s)=\left(s^{2}+2 \zeta_{n} \omega_{n} s+\omega_{n}^{2}\right) / \omega_{n}^{2} \\
& G_{a c}(s)=k_{a}\left(1+T_{a 1} s\right) /\left(1+T_{a 2} s\right)
\end{aligned}
$$




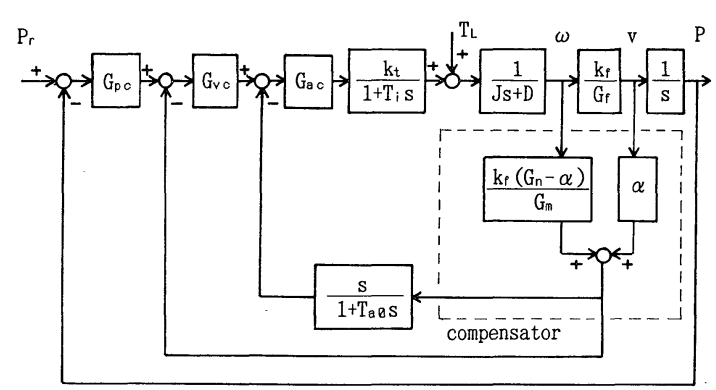

Fig. 3 Load insensitive servomechanism for elastic feeding mechanism

$$
\begin{aligned}
& G_{v_{c}}(s)=k_{v}\left(1+T_{v 1} s\right) / T_{n 1} s \\
& G_{p_{c}}(s)=k_{p}\left(1+T_{p_{1} s} s\right) / T_{p_{1}} s
\end{aligned}
$$

\section{4. 制振補償器と負荷無反応形 サーボ系の設計}

本論文で提案するサーボ系は制振補償器が内部に構 成され，それによって得られた情報を利用して速度掞 よび加速度の制御ループが構成される.さらに，位置 制御ループとともに負荷無反応形サーボ系として機能 させることを考えている，そこで，位置，速度および 加速度制御ループのそれぞれの制御器の設計方針なら びに制振補償器が安定に動作するための条件とその性 質について以下に説明する.

\section{1 加速度制御ループの設計}

Fig. 3 より加速度制御ループを取り出すと Fig. 4 のようになる，このループの一巡伝達特性の相対次数 は - 2 であるから理論上制御ゲイン $k_{a}$ を十分大きく 設定することができる，いま，加速度算出の遅れを補 償する立場から $T_{a 1}=T_{a 0}$ とし，また $T_{a 2} \omega_{n} \ll 1$ とな るように設計すれば, 加速度ループの伝達関数はつぎ のように近似される。

$$
G_{a}(s) \fallingdotseq \frac{\left(1+T_{a 0} s\right) G_{m}(s)}{G_{n}(s) G_{f}(s)+\alpha\left(G_{m}(s)-G_{f}(s)\right)}
$$

ここで補償器におけるモデル特性 $G_{m}$ の実特性 $G_{f}$ に対する一致度がよい場合にはさらに(11)式のように 簡略化される.

$$
G_{a}(s) \fallingdotseq\left(1+T_{a 0} s\right) / G_{n}(s)
$$

このように望ましい設定によれば加速度制御ループ

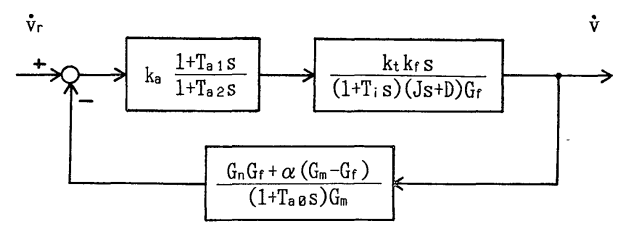

Fig. 4 Block diagram of acceleration control loop
の伝達特性は振動的要素を含む実系の特性に依存せず 補償器の指定特性 $G_{n}$ によって支配されることになる. ここでは，制振性能を考慮して指定特性 $G_{n}$ の減衰係 数を $\zeta_{n}=1$ のように設定する.なお，後の説明のため に Fig. 5 亿加速度制御ループの根軌跡を示した.

\section{2 速度制御ループの設計}

(8)式と(11)式を利用して Fig. 3 の系から速度制 御ループを取り出すと Fig. 6 のようになる. ここで,

$$
\begin{aligned}
& T_{v 1} \omega_{n} \gg 1 \\
& k_{v} \gg \omega_{n}
\end{aligned}
$$

のように設計すると， Fig. 7 に示されている速度制 御ループの根軌跡からわかるように, 速度制御ループ の伝達特性 $G_{v}$ は次式のように近似できる.

$$
G_{v}(s) \fallingdotseq 1 / G_{n}(s)=1 /\left(1+s / \omega_{n}\right)^{2}
$$

\section{3 位置制御ループの設計}

(9)式と(14)式を利用して Fig. 3 の系から位置制 御ループが Fig. 8 のように得られる. 制振を目的と

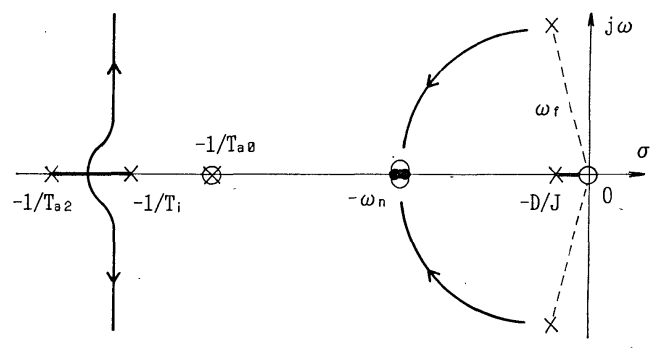

Fig. 5 Root locus of acceleration control loop

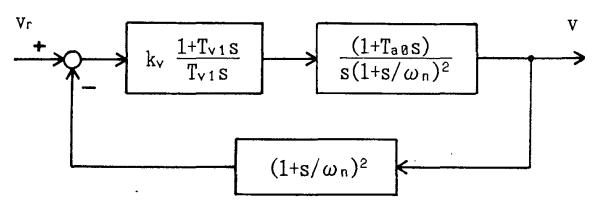

Fig. 6 Block diagram of velocity control loop

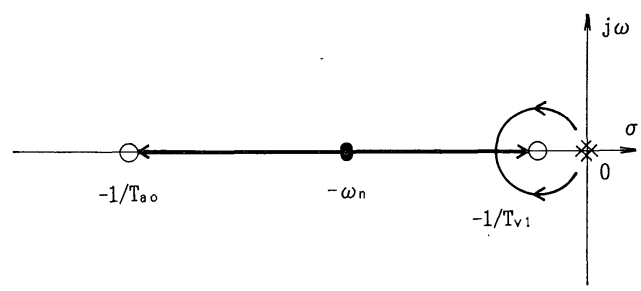

Fig. 7 Root locus of velocity control loop

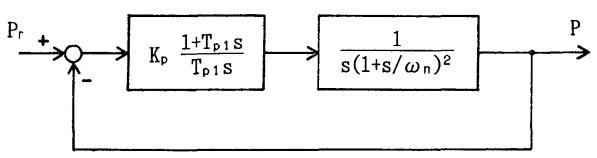

Fig. 8 Block diagram of position control loop 


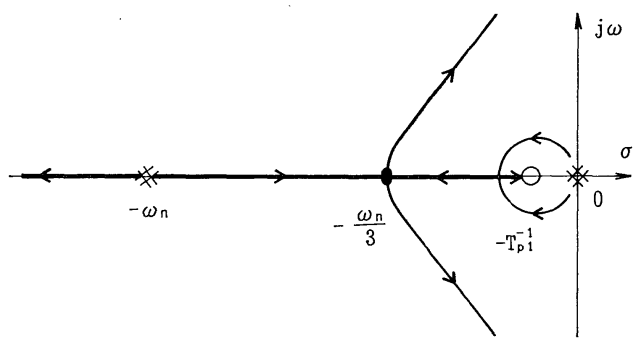

Fig. 9 Root locus of position control loop

した場合，位置制御系の応答特性は臨界減衰あるいは 過減衰となるように設計するととが望ましい。すなわ ち，Fig. 9 の根軌跡に示したように代表根を実軸上 に配置するように設計する。乙のときの条件は(15) お よび(16)式のようになる.

$$
\begin{aligned}
& T_{p 1} \omega_{n} \gg 1 \\
& k_{p} \leqq 4 \omega_{n} / 27
\end{aligned}
$$

ここで，臨界減衰応答を示すように設計するとすれ ば位置制御ループのゲインを $k_{p}=4 \omega_{n} / 27$ とすればよ い. このとき，乙の分岐点の值を $-1 / T_{p}$ とすると， $T_{p}=3 / \omega_{n}$ で与えられる.したがって，位置制御ルー プつまりサーボ系の伝達特性 $G_{p}$ はつぎのように近似 できる。

$$
G_{p}(s) \fallingdotseq 1 /\left(1+T_{p} s\right)^{2}
$$

負荷のモデリング誤差などを考慮に入れて，過減衰 となるように $k_{p}$ の值を設定する.

\section{4 制振補償器の設計}

ここで提案する制振補償器によって制御系が安定に 動作するためには(10)式の分母が安定多項式でなけれ ばならない. そこで,

$$
\begin{aligned}
& G_{n} G_{f}+\alpha\left(G_{m}-G_{f}\right) \\
& \quad=\left(s^{4}+A_{1} s^{3}+A_{2} s^{2}+A_{3} s+A_{4}\right) / A_{4}
\end{aligned}
$$

と拈いて，Hurwitz の条件を適用すれば

$$
\begin{aligned}
A_{1}= & 2\left(\zeta_{f} \omega_{f}+\zeta_{n} \omega_{n}\right)>0 \\
A_{2}= & \omega_{f}^{2}+\omega_{n}^{2}+4 \zeta_{f} \omega_{f} \zeta_{n} \omega_{n}+\alpha\left(\omega_{f}^{2}-\omega_{m}^{2}\right) \omega_{n}^{2} / \omega_{m}^{2}>0 \\
A_{3}= & 2\left(\zeta_{n} \omega_{n} \omega_{f}^{2}+\zeta_{f} \omega_{f} \omega_{n}^{2}\right. \\
& \left.+\alpha\left(\zeta_{m} \omega_{m} \omega_{f}^{2}-\zeta_{f} \omega_{f} \omega_{m}^{2}\right) \omega_{n}^{2} / \omega_{m}^{2}\right)>0 \\
A_{4}= & \omega_{n}^{2} \omega_{f}^{2}>0 \\
H_{1}= & A_{1}>0 \\
H_{2}= & A_{1} A_{2}-A_{3}>0 \\
H_{3}= & A_{1} A_{2} A_{3}-A_{3}^{2}-A_{1}^{2} A_{4}>0
\end{aligned}
$$

のような制約条件が得られる。こてで，

$$
\omega_{n} \geqq \omega_{f} \geqq \omega_{m}, \quad 1 \geqq \alpha \geqq 0
$$

のように設計すれば，(19)〜 (24) 式の条件は満たされ る。(25)式の条件も同時に満たしていれば安定性が保 証される.ただし， $\alpha$ は定数として考えている.

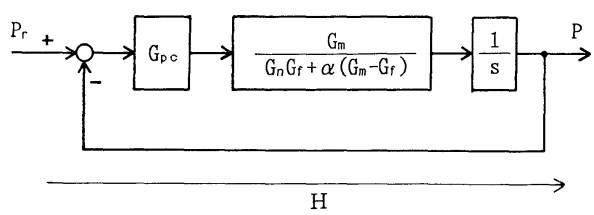

Fig. 10 Block diagram of position control loop considering modelling error

(25) および (26) 式が成立すれば，モデル特性 $G_{m}$ に (26) 式で許される䛊差が存在しても制御系は安定に動 作し, 逆に(26)式の範囲での実系 $G_{f}$ の特性変動があ っても制御系は安定に動作するととになる.

つぎに， $\alpha$ の值について感度の観点から検討する。 いま，ゲイン $k_{a}$ と $k_{v}$ は十分大きいとし，モデル特 性に誤差があると考えると，位置制御系の特性を示し た Fig. 8 は Fig. 10 のように書き直すことができる. この場合の実系パラメータに関する感度 $S$ を考えると つぎのようになる。

$$
\begin{aligned}
S= & \frac{1}{H} \frac{\partial H}{\partial G_{f}} \frac{\partial G_{f}}{\partial \theta} \quad\left(\theta=\omega_{f}, \zeta_{f}\right) \\
= & \frac{1}{\left(\alpha s^{2}+k_{p} s+k_{p} / T_{p_{1}}\right) G_{m} /\left(G_{n}-\alpha\right) s^{2}+G_{f}} \\
& \times \begin{cases}2\left(s / \omega_{f}\right)^{2}\left(s / \omega_{f}+\zeta_{f}\right) \cdots \theta=\omega_{f} \\
-2 s / \omega_{f} & \cdots \theta=\zeta_{f}\end{cases}
\end{aligned}
$$

ここで初期值と最終值に関する感度 $S$ を求めるとつ ぎのようになる。

$$
\begin{aligned}
& S_{0}= \begin{cases}2 T_{p_{1}} \zeta_{f}(1-\alpha) \boldsymbol{O}\left(s^{3}\right) / \omega_{f}^{2} k_{p} & \theta=\omega_{f} \\
-2 T_{p_{1}}(1-\alpha) \boldsymbol{O}\left(s^{3}\right) / \omega_{f} k_{p} & \theta=\zeta_{f}\end{cases} \\
& S_{\infty}= \begin{cases}2 / \omega_{f} & \theta=\omega_{f} \\
-2 \omega_{f} \boldsymbol{O}\left(s^{-1}\right) & \theta=\zeta_{f}\end{cases}
\end{aligned}
$$

この結果からわかるように， $\alpha=1$ とすれば実系 パラメータに関する感度を最む低く抑えるととができ る.

\section{5. シミュレーション}

\section{1 シミュレーションにおける数值条件}

Fig. 1 の実系のパラメータを以下のようなむのと する.

$$
\begin{array}{ll}
T_{i}=0.5 \mathrm{~ms} & k_{t}=0.49 \mathrm{~N} \cdot \mathrm{m} / \mathrm{A} \\
J=9.8 \times 10^{-3} \mathrm{~N} \cdot \mathrm{m} \cdot \mathrm{s}^{2} & D=0.98 \times 10^{-3} \mathrm{~N} \cdot \mathrm{m} \cdot \mathrm{s} \\
k_{f}=30 \mathrm{~mm} / \mathrm{rev} & \omega_{f}=100.0 \mathrm{rad} / \mathrm{s} \\
\zeta_{f}=0.01 & T_{L}=1.96 \mathrm{~N} \cdot \mathrm{m}
\end{array}
$$

位置サーボ系の応答時定数を $66.7 \mathrm{~ms}$ とし，4 章で 示した手法を用いて Fig. 3 のサーボ系に抬ける制振 補償器および各ループの制御器を以下のように設計で きる.

$$
\omega_{m}=100 \mathrm{rad} / \mathrm{s} \quad \zeta_{m}=0.01
$$




$$
\begin{aligned}
& \omega_{n}=200 \mathrm{rad} / \mathrm{s} \quad \zeta_{n}=1.0 \\
& \alpha=1.0 \\
& k_{p}=15 \mathrm{~s}^{-1}<\left(4 \omega_{p} / 27=30 \mathrm{~s}^{-1}\right) \\
& T_{p 1}=10 \mathrm{~s} \gg \omega_{n}^{-1} \\
& k_{v}=400 \mathrm{~s}^{-1} \gg \omega_{n} \\
& T_{v 1}=0.5 \mathrm{~s} \gg \omega_{n}^{-1} \\
& k_{a}=1000 \mathrm{~A} \cdot \mathrm{s}^{2} / \mathrm{m} \\
& T_{a 1}=T_{a 0}=1.0 \mathrm{~ms} \\
& T_{a 2}=0.5 \mathrm{~ms} \ll \omega_{n}^{-1}
\end{aligned}
$$

\section{2 シミュレーション結果}

Fig. 3 のサーボ系に対してランプ状の位置指令を 与える定速運転 (指令速度 $0.5 \mathrm{~m} / \mathrm{s}$ ) のシミュレーシ ヨンを行った。まず，制振補償器におけるモデル特性 にモデリング詰差がない場合の結果を Fig. 11 亿示 す.ここでは同時に矩形波状の外乱トルク $T_{L}$ が加え
られており，その際の速度ひおよび電流 $i$ 挙動が示 されている，乙のようにその応答は振動的要素および 外乱トルクの影響を受けずに設計值通りの結果となっ ているととがわかる。

つぎに，モデル特性に打ける固有角周波数にモデリ ング誤差があると仮定し， $\omega_{f}=150(\mathrm{rad} / \mathrm{s})$ とした場合 の結果を Fig. 12 亿示す.との結果より，4章で解析 したように，モデリング誤差があってあ， $\omega_{f}>\omega_{m}$ で あればサーボ系は安定に動作することがわかる，さら に，モデル特性に括ける減衰係数にモデリング誤差が ある場合として， $\zeta_{f}=0.02$ および 0.005 としたとき の応答を Fig. 13, Fig.14 亿示す。てれらより，減 衰係数のモデリング誤差に対して低感度であることが わかる。

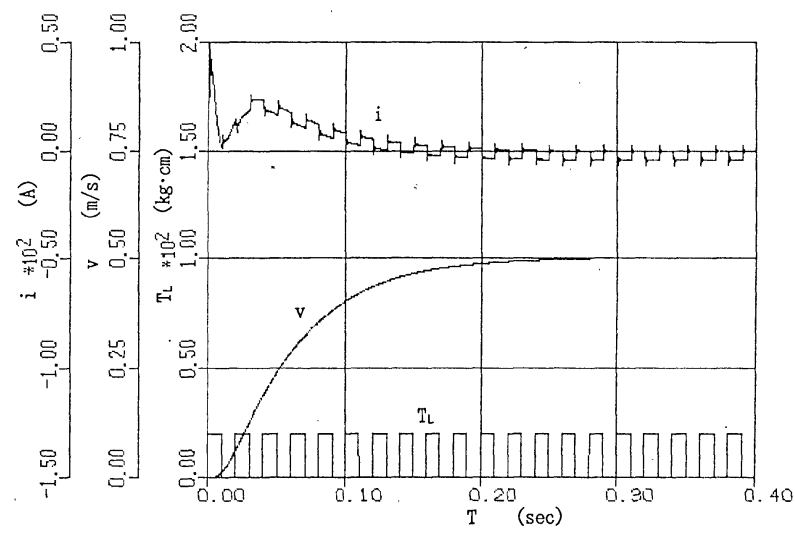

Fig. 11 Result of simulation in case of not existing modelling error

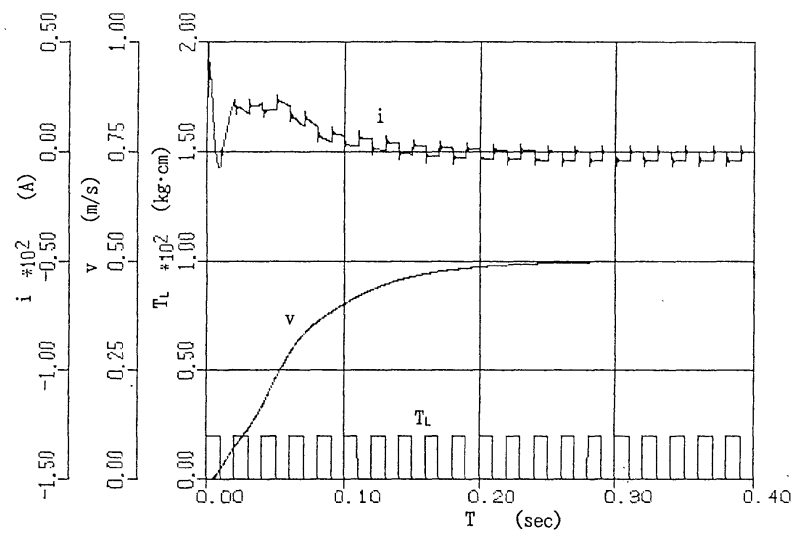

Fig. 12 Result of simulation in case of existing modelling error of natural angular frequency $\omega_{f}$ 


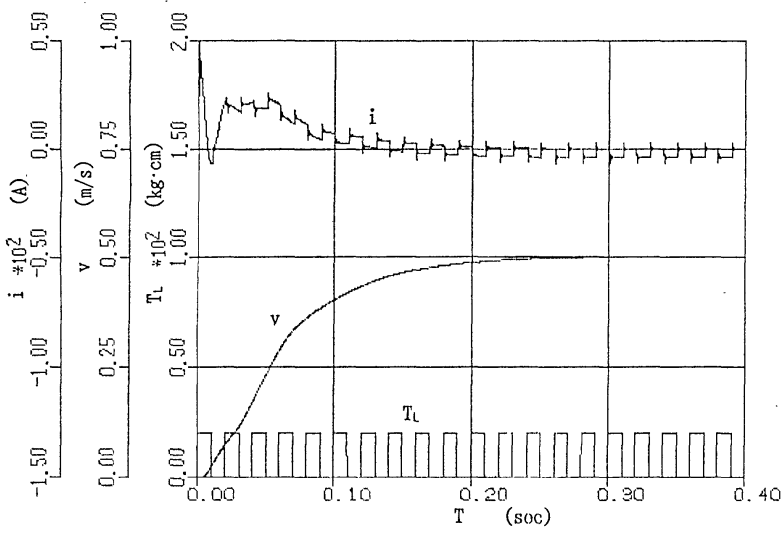

Fig. 13 Result of simulation in case of mismatching of damping coefficient $\zeta_{f}$ (underestimation)

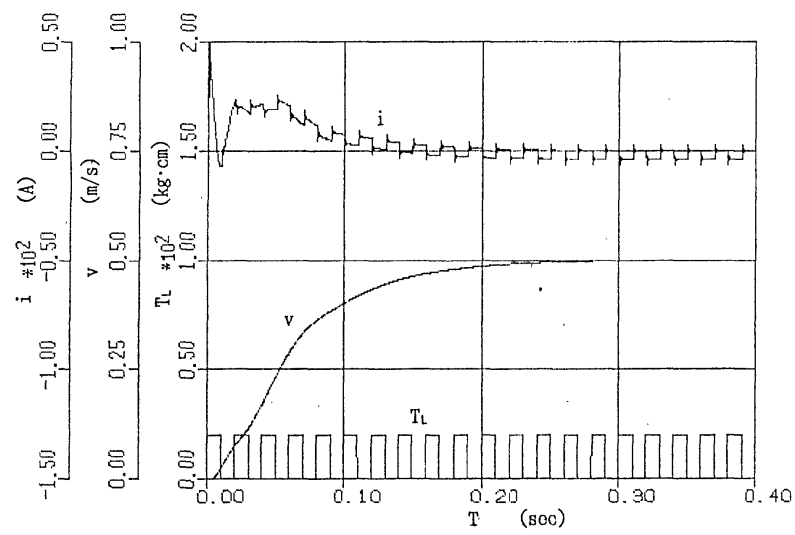

Fig. 14 Result of simulation in case of mismatching of damping coefficient $\zeta_{f}$ (overestimation)

\section{6. おわりに}

本論文は実系における振動的要素の特性を補償でき る新しい制振補償器と制振制御を加味した負荷無反応 形サーボ系を提案した。すなわち，

（1）実系を非振動的で相対次数が 0 -2 の部分 と振動的要素を含む部分とに分け, 実系を含む制御系 の一巡伝達特性の相対次数を 0 〜 2 に収めるように するため, 振動的要素の入力側と出力側との検出情報 をともに相対次数零の伝達要素を介して結合フィード バック情報を生成した。

（2）乙の生成のため新しい制振補償器を導いた。

（3）乙の制振補償器には振動的要素の特性に依存 しない所望の指定特性をあたせることができた.

（4）乙の指定特性が発揮される条件を明らかにし た.
（5）乙の制振補償器を用いた位置制御系では，制 御対象である振動的要素の送り速度は, この要素の固 有角周波数の変動, 減衰係数の変動, 印加外乱などに 対して負荷無反応であるてとをシミュレーションによ り確認した.

おわりにのぞみ，貴重なご指導を賜った東京工業大 学の中野道雄教授に深甚の謝意を表したい.

\section{参 考 文 献}

1) 池辺, 中田, 横田, 横山：負荷無反応形電気・油圧サー ボ系, 計測自動制御学会論文集, 16-3,391/397 (1980)

2) 大梘, 平井, 池辺: 負荷無反応形電気サーボ系, 計測自 動制御学会論文集, 21-10, 1080/1085 (1985)

3) 中野道雄: パラメータ変動とアクチニエータ系の構成に 関する考察，計測自動制御学会論文集，24-12, 1349/1351 (1988)

4) 大西公平：メカトロニクスにおける新しいサーボ系，電 気学会論文誌 $D, 107-1,83 / 86(1987)$ 
5) 水谷, 山極, 張, 岡本：外乱トルクオブザーバによる FF 補償の負荷無反応性とその性質, 第 32 回自動制御連 合講演会前刷, 83/86 (1989)

6) 堀 洋一: 加速度制御形サーボ系, 電気学会論文誌 D, 108-7, 673/677 (1987)

7) 山極, 岡本, 水谷, 張: 負荷無反応形サーボ系, ロボテ ィクス・メカトロニクス講演会 '90 講演論文集 B，155/ $158(1990)$

8) 楯, 日比野, 平井: 機械共振を補償するディジタルコン トローラ, 第 28 回自動制御連合講演会前刷, 307/308 (1985)

9) 二見 茂：機械共振特性を安定化する位置制御方式，昭 和 62 年度精密工学会秋期大会学術講演会講演論文集, 339/340 (1987)

10）二見 茂：加浐度のポジティブフィードバックにより機
械振動特性を安定化した位置制御，第31 回自動制御連合 講演会前刷，467/470 (1988)

11）二見 茂 : 機構振動を考慮した位置制御系の PI と I-P 速度制御の比較, 精密工学会誌, 54-8, 1469/1474 (1988)

12) 小山正人：低剛性な負荷機械を駆動する電動機の各種速 度制御系の特性比較, 電気学会論文誌 D, 107-8, 1010/ 1017 (1987)

13）島田 明：オブザーバを用いた低剛性負荷の振動抑制制 御之特性解析, 第 32 回自動制御連合講演会前刷, 89/90 (1989)

14) 岡本, 水谷, 張: 負荷無反応形サーボ系, ロボティクス・ メカトロニクス講演会'90講演論文集 B, 325/328 (1990)

15) 水谷, 大庭, 岡本: 柔結合送り機構の反作用トルク補償 とその定常振動抑制効果, 第3 2 回自動制御連合講演会前 刷, 155/158 (1989) 